\title{
'n Paradigma vir Gereformeerde teologiese wetenskapsbeoefening - 'n voorstel
}

\author{
H.J.M. van Deventer \\ Departement Bybelkunde \\ Potchefstroomse Universiteit vir $\mathrm{CHO}$ \\ Vaaldriehoekkampus \\ VANDERBIJLPARK
}

\begin{abstract}
A paradigm for practising Reformed theology - a proposal

In the present article the term paradigm, as used in theology, is outlined. The extsting paradigms within theology are investigated and it is indicated that the view of Scripture senes as a basic premise in each paradigm. It is further shown that paradigm (view of Scripture) and method (interpretation of Scripture) need not be in tandem. This means that theology can be practised within a cerlain paradigm by using a number of methods. These results are applied to the Faculty of Theology of the "PU vir CHO".
\end{abstract}

\section{Inleiding}

Die titel van hierdie artikel bevat enkele begrippe wat nader omskryf moet word. Rondom die gebruik van die begrip paradigma heers daar reeds sedert Kuhn (1962) se gebruik daarvan binne 'n ander wetenskaplike konteks 'n Babelse verwarring (vgl. M.E. Botha, 1989:194-196; Conradie, 1994:83; Shapere, 1980). Een van die oogmerke van hierdie artikel is daarom juis om die begrip paradigma vir die doeleindes van hierdie artikel te omskryf

Die begrippe Gereformeerde en teologiese wetenskapsbeoefening is albei gelade, en daarom 'n verduideliking van wat daarmee bedoel word. Gereformeerde dui in hierdie artikel in die eerste plek op die teologiese wetenskapsbeoefening ${ }^{1}$, soos dit vergestalt word binne 'n sekere denominasionele gemeenskap, te wete die Gereformeerde Kerke in Suid-Afrika (GKSA). Hierdie studie sal daarom tot 'n groot mate fokus op die werk wat binne die Fakulteit Teologie van die PU vir

1 Hicrdic artikel fokus nic op dic gereformeerde Tcologic in die algemeen nic, maar op dic vergestalting daarvan deur Gereformecrde tcoloc binne die Departement Ou en Nuwe Testament van dic Fakulteit Tcologic aan dic PU vir CHO Dic veld word verder begrens deur slegs dic werk van enkele Ou-Testamentici wat aan hicrdic Departement verbonde is/was in aanmerking te ncem 
$\mathrm{CHO}^{2}$ gedoen word, omdat daar 'n besondere band tussen hierdie Fakulteit en die GKSA bestaan. In die tweede plek dui gereformeerde ook op 'n bepaalde tradisie van teologiese wetenskapsbeoefening, te wete die tradisie voortspruitend uit die sestiende-eeuse Reformasie.

Die begrippe teologiese wetenskapsheoefening veronderstel dat God tot 'n sekere mate geken kan word deur sy tweërlei openbaring (die Bybel en die skepping) ${ }^{3}$. Dit hou dus verband met die voor-Verligtinggedagte 4 dat kennis van die metafisiese "van bo af" bekom kan word5. Wetenskaplikes wat met hierdie "voor-Verligting"-siening gebreek het, beskou hulself daarom eerder as Bybelwetenskaplikes, omdat die Bybel as woorde oor God bestudeer word en nie as Woord van God waardeur Hy Homself bekend maak nie (vgl. Spangenberg, $1994)^{6}$.

\section{Wat is 'n paradigma?}

Dit kan seker sonder veel vrees vir teëspraak gestel word dat Thomas S. Kuhn beskou kan word as die vader van die begrip paradigma soos wat dit vandag in die wetenskapsteorie gebruik word, omdat sy gebruik van hierdie begrip, wat reeds deur onder andere Toulmin en Polyani gebruik is (vgl. M.E. Botha,

2 Die feit dat dic PU vir CHO 'n universiteit op Christclike grondslag is, verdien ook 'n opmerking. Rondom dic begrip Christelike universiteit moct opgemerk word dat 'n universiteit as instelling (struktuur) nic per se Christelik kan wees nie Met "Christclike universiteit" word bedocl dat gepoog word om dic wetenskap vanuit 'n "Christelike perspekticf" tc beocfen (Bingle, 1976:22, vgl. Ouweneel, 1993:323). Hicrdic "Chrıstclike perspckticf" stcl egter nic een bepaalde uitkyk voor nic, omdat daar binne die Christendom inderdaad baic "perspektiewe" is Juis om hicrdic "Christelike perspckticf" duideliker tc omlyn, word daar vanuit 'n bepaalde konfessionele standpunt gewerk. Dic konfessionele vertrekpunt van die PU vir $\mathrm{CHO}$ in dic bcoefening van Christelike wetenskap is dic dric formuliere van cenheid. Hierdie vertrekpunt is ontleen aan dic Teologiesc Skool van dic GKSA, waaruit dic PU vir CHO gegroei het

3 Dit val nic binne die skopus van hicrdie artikel om in bespreking en omskrywing van die aard en taak van tcologic te gec nic; dus word daar met hicrdic simplisticse voorstelling volstaan Vir 'n bespreking van dic aard en taak van teologic kyk Conradic (1994)

4 Zuiddam (1995:256) probeer egter aantoon dat die (histories) kritiese benadering tot die Bybel ook teruggaan tot voor dic Verligting, naamlik na dic filosowe Celsus en Porphirius gedurende dic tweede en derde eeue n.C. - 'n benadering wat veral dic idec van dirckte goddclike openbaring tecngestaan het.

5 Dic Verligting het 'n ondeurdringbare skeiding tussen dic fisiese en metafisiese daargestel Menslike kennis is beperk tot dic fisicse wereld en daarom is kennis van God ook slegs vanuit die fisiese wereld moontlik. Vanuit hierdie vooronderstelling is dic Bybel bestudecr om daarin menslike woorde (nadenke) oor God tc vind

6 Vir sodanige wetenskaplikes sal dic begrippe teologiese wetenskapsbeoefening inderdaad 'n teenstrydigheid kan inhou 
1990:62), inslag gevind het. In sy epogmakende werk The Structure of Scientific Revolutions (wat in 1962 verskyn het) toon Kuln aan hoedat daar binne die (natuur) wetenskappe veranderings (omwentelinge) plaasgevind het. Hierdie omwentelinge word beskou as rewolusies waartydens 'n vroeëre algemeen aanvaarbare siening met betrekking tot die veld van ondersoek vervang word deur 'n totaal nuwe siening met betrekking tot daardie veld. Hierdie omwenteling vind onder andere plaas ondat die vroeere siening nie meer bydra om huidige probleme binne die veld van ondersoek op te los nie.

Kuhn het onder heelwat kritiek deurgeloop. In hoofsaak het Kulın se kritici gefokus op sy vae definiëring van die begrip paradigma en daarmee saam sy geslote siening van wetenskaplike gemeenskappe waarbinne konsensus volgens hom sou heers (vgl. Shapere, 1980:27-38; Musgrave, 1980:39-53). Hierdie kritiek het Kuhn genoop om in 'n volgende uitgawe van sy aanvanklike werk (1970) 'n naskrif by te voeg waarin hy sy idees noukeuriger omlyn het. Hieruit blyk dat die idee van 'n paradigma fokus op "die metafisiese stel oortuigings wat deur die gemeenskap van geleerdes aangehang word" (M.E. Botha, 1989:194)

Hierdie stel oortuigings huisves egter nie van meet af aan ' $n$ identifiseerbare stel reëls wat aan die gemeenskap 'n bepaalde aard gee nie. Kuhn (1970:45-6) stel dit soos volg: "Instead, they may relate by resemblance and by modeling to one or another part of the scientific corpus which the community in question already recognizes as among its established achievements". 'n Stel reëls wat 'n wetenskaplike gemeenskap lei, is moeilik om te ontdek en te beskryf. Hierdie proses van die oopdekking van die reels eie aan 'n bepaalde paradigma vind eers plaas wanneer ' $\mathrm{n}$ krisis in die veld van ondersoek teëgekom word (Kuhn, 1970:48). Hierdie reëls kan verband hou met geldige metodes, probleme en standaarde van oplossings en kan, anders as 'n paradigma per se, gemeenskaplik wees binne 'n breë wetenskaplike gemeenskap (Kuhn, 1970:48, 49). Aan die ander kant hoef konsensus bimne 'n bepaalde wetenskaplike gemeenskap nie noodwendig deurgetrek te kan word na die metafisiese (paradigmatiese) nie (Musgrave, 1980:44). Toegepas op die teologiese wetenskap en die bibliologiese vakgroep in besonder, kan dus opgemerk word dat elke paradigma oor 'n implisiete stel reëls beskik. Hierdie stel reêls kan verband hou met metodes in die wetenskap, maar is nie noodwendig bepalend vir die metodes nie.

'n Paradigma is begrond op 'n stel "oortuigings" (heliefs) wat weer gebaseer is op 'n korpus wat die gemeenskap reeds aanvaar het (vgl. Kuhn, 1970:45-6). In die Bybelwetenskappe hou hierdie oortuigings onder andere verband met die siening van die Bybel. Binne 'n bepaalde gemeenskap kan die Bybel gesien word as "Woord van God", binne 'n volgende as "Gods Woord in mensetaal" en binne 'n derde gemeenskap as "Woorde oor God". Elkeen van hierdie gemeenskappe sal bepaalde metodes aanwend vir probleemoplossing, maar hierdie metodes hoef 
nie so uitsluitend te wees dat dit nie binne die ander paradigmas gebruik kan word nie (vgl. Kuhn, 1970:49). Verder is dit moontlik dat meer as een paradigma vir 'n tyd lank kan funksioneer binne 'n bepaalde navorsingsgemeenskap, veral gedurende 'n oorgangsfase wanneer een paradigma vervang word met 'n volgende.

In hierdie artikel word die term paradigma dus gebruik om daarmee 'n metafisiese model aan te dui - 'n model wat dien as vertrekpunt vir die navorsing binne 'n sekere navorsingsgemeenskap (vgl. Kuhn, 1970:10). 'n Paradigmaverskuiwing vind plaas wanneer die bestaande model verruil word vir 'n ander (nuwe) model, hoofsaaklik (maar nie noodwendig) vanweë die feit dat die ouer model nie meer resente probleme in die veld van ondersoek kan oplos nie. In die Bybelwetenskappe kan 'n nuwe paradigma verband hou met 'n ander siening aangaande die Bybel.

\section{Bestaande paradigmas binne die teologiese wetenskap}

Spangenberg (1994) se siening in verband met paradigmaverskuiwinge binne die Bybelwetenskappe gee 'n kort samevatting van die paradigmas binne die teologiese wetenskap. Teenoor Lategan (1984), wat eintlik net twee paradigmaverskuiwinge in die navorsingsgeskiedenis van die Bybelwetenskappe voorstel, naamlik eerstens die verskuiwing in ondersoek van die outeurspool (bron) (as eerste fase in die navorsingsgeskiedenis) na die tekspool (boodskap), en tweedens die verskuiwing van die tekspool na die ondersoek aangaande die rol van die leser (ontvanger), stel Spangenberg (1994:156) drie paradigmaverskuiwinge in die Protestantse tradisie voor: eerstens die skuif wat die benadering van die Hervorming teweeggebring het, tweedens die skuif vanaf die Hervormingsbenadering na die histories-kritiese benadering en laastens die skuif vanaf die histories-kritiese benadering na die moderne literatuurwetenskaplike benadering 7 .

Spangenberg (1994:148) gee die volgende opsommings van die drie paradigmas: die paradigma van die Hervorning gaan uit van die idee dat "die Bybel ... die Woord van God [is]. Deur hierdie Woord openbaar God Homself aan die gelowige mens. Die indlwiduele gelowige wat gelei word deur die Heilige Gees kan die Bybel reg interpreteer omdat die Bybel duidelik en sy eie uitlegger is Vir 'n korrekte uitleg is die gelowige, afgesien van die leiding van die Gees, aangewese op die histories-letterlike interpretasiewyse" (kursivering - Spangenberg).

Spangenberg (1994 157) se kritiek op Lategan dat laasgenoemde se model slegs van toepassing is op paradigmaverskuiwinge binnc dic literatuurwetenskap en nie op paradigmaverskuiwinge in die Bybelwetenskappe nie, is gepas (vg] Longman, 1987:18). 
H.J.M. van Deventer

Die paradigma van die historiese kritiek word soos volg saamgevat (Spangenberg, 1994:156):

[d]ie Bybel is ' $n$ versameling Ou Nabye-Oosterse godsdienstige geskrifte wat deur beperkte, feilbare mense geskryf is. Verskeie van hierdie geskrifte het oor 'n lang periode ontstaan en is dikwels nie net deur een outeur geskryf nie. Die geskrifte bevat die geloofsinsigte en geloofsgetuienisse van daardie mense en hul tydgenote. Hierdie mense het gedurende 'n vasomlynde tyd in die geskiedenis op aanwysbare plekke op aarde geleef. Vir 'n korrekte verstaan van die Bybel moet die leser oor grondige kennis beskik van onder andere (1) die geskiedenis van Israel en ander Ou NabyeOosterse volke asook die vroeë Christendom; (2) die kulturele milieu ... van daardie mense; (3) hulle wêreldbeeld; (4) die godsdienstige oortuigings, praktyke en strominge van daardie tyd.

Spangenberg (1994:161) som die paradigma van die modene literatuurwetenskaplike benadering soos volg op:

... die Bybel [word beskou] as ' $n$ versameling $O u$ Nabye-Oosterse godsdienstige literatumr. Hierdie literatuur kan volgens die gangbare literatuurwetenskaplike metodes ... ontleed word. Vanweë die nuwere ontwikkeling in die literatuurwetenskap word die klem tans meer geplaas op die leser (reseptor) van die teks (kursivering - Spangenberg).

Die rede waarom daar sprake is van ' $n$ nuwe paradigma in bogenoemnde gevalle is volgens Spangenberg (1994:160) “ondat daar op 'n nuwe manier na die Bybel gekyk word". Die drie maniere van kyk na die Bybel binne die bogenoemde drie paradigmas word soos volg opgesom: binne die Hervormingsparadigma word die Bybel as "Woord van God" gesien, binne histories-kritiese paradigma as "Gods Woord in mensetaal" en binne die literêr-wetenskaplike paradigma as "Woorde oor God" (Spangenberg, 1994:161). Dit is egter 'n vraag of die siening van die Bybel binne die laasgenoemde twee paradigmas wel so duidelik onderskeibaar is. Die rede vir die "ander" sienings van die Bybel word ook deur Spangenberg (1994:145, 153) benadruk, naamlik dat daar 'n krisis rondom die gebruik van 'n bepaalde paradigma ontstaan het (vgl. Kuhn, 1970:66-76). Hierdie krisis word egter net met betrekking tot die Hervonningsparadigma geillustreer (Spangenberg, 1994:153). Geen duidelik aantoonbare krisis ${ }^{8}$ met die historieskritiese paradigına het aanleiding gegee tot die gebruik van die "literêrwetenskaplike" paradigına nie. Spangenberg (1994:159) se eie beskrywing van hierdie derde paradigmaverskuiwing lyk eerder na 'n organiese ontwikkeling

In sy "Postscript - 1969" gee Kuhn (1970:181) inderdaad toe dat 'n paradigmaverandering nic noodivendig hoef te dui op $n$ groot verandering nie, maar dat mikro-rcwolusies kan plaasvind wat nie noodwendig deur' 'n krisis voorafgegaan hoef te word nie 
'n Paradigma vir Gereformeerde teologiese wetenskapsbeoefening - 'n voorstel

(lynreg teenoor Kuhn se annvanklike siening van ontwikkeling in die wetenskap) as na 'n rewolusie (Kulun, 1970:92-110). Spangenberg beskryf hierdie verskuiwing soos volg:

Die rede waarom sommige Bybelwetenskaplikes vanuit 'n nuwe paradigma begin werk het, was nie soseer omdat hulle van oordeel was dat die Histories-kritiese benadering misluk het nie, maar omdat hulle besef het dat 'n historiese benadering nie die enigste benadering tot literatuur hoef te wees nie

Dit kan inderdaad gevra word of laasgenoemde twee paradigmas, volgens Spangenberg se beskrywing, "incommensurable" is (Kuhn, 1970:103) en of daar wel gepraat moet word van 'n paradigmaverskuiwing? Hasel (1991:132-133) meen dat daar inderdaad van 'n paradigmaverskuiwing gepraat kan word vanweë die ontoereikendheid van die histories-kritiese paradigma en "its failure to free the Bible from the past".

In al hierdie omskrywings van die verskillende paradigmas in die teologie kan twee komponente onderskei word, naamlik 'n bepaalde Skrifbeskouing en 'n bepaalde metode van Skrifverklaring (vgl. Spangenberg, 1994:160). Die vraag ontstaan egter of ' $n$ bepaalde Skrifbeskouing noodwendig, soos Spangenberg wil te kelne gee, moet saamhang met 'n bepaalde metode van Skrifverklaring. Jordaan (1991:30) neem hom byvoorbeeld voor om vanuit die Skrifbeskouing van die Hervorming (om Spangenberg se terminologie te gebruik) "[v]an die moderne ontwikkelinge en verfyninge in die hermeneutiek gebruik [te] maak en daarop voort [te] bou". Hierdie opmerking is in ooreenstemming met dit wat onder die vorige punt benadruk is, naamlik dat Skrifbeskouing en metode van Skrifverklaring nie albei as vaste grondreël binne elke paradigma hoef te geld nie

'n Verdere voorbeeld in hierdie verband is die werk van H.F. van Rooy wat self meld (1995:59) dat hy nie net met die "tradisionele gereformeerde benadering" tot Skrifverklaring werk nie. Hy neem kennis van historiese metodes, waaronder sosiologiese metodes. Hiermee word bedoel dat hy hierdie metodes gebruik in sy wetenskapsbeoefening. In hierdie verband kan gelet word op die verskillende metodes wat Van Rooy in sy wetenskapsbeoefening gebruik: die gebruik van histories-kritiese (redaksiegeskiedenis en sosiologiese) metodes (Van Rooy, 1988); die gebruik van histories-kritiese (tradisiegeskiedenis) metodes (Van Rooy (1993); en die gebruik van histories-kritiese (sosiologiese) metodes (Van Rooy, 1994b). Dieselfde metode van Skrifverklaring kan deur 'n wyer wetenskaplike groep (wat vanuit verskillende paradigmas werk) gebruik word. Hierdie wyer gebruik van metodes word deur Beuken $(1994: 26,27)$ aangetoon as ook geldend binne die groep Ou-Testamentiese navorsers in Europa. In hierdie lig is dit te bevraagteken of Deist en Burden (1983:116) reg het as opgemerk word dat sekere metodes mekaar "afstoot" en eenvoudig nie "paarbaar" is nie. 
Hierdie opmerking geld eerder paradigmas as metodes. Die navorser wat werk vanuit die Hervormingsparadigna kan dus 'n bepaalde histories-kritiese metode gebruik in sy/haar analise van die teks van die Bybel, sonder om daarmee sy/haar siening van die Bybel as Woord van God te verander. Die voorrang wat daar binne bepaalde paradigmas aan sekere metodes gegee word (byvoorbeeld die gebruik van literêre metodes waar die Bybel gesien word as "'n versameling $\mathrm{Ou}$ Nabye-Oosterse literatuur") is egter nie so paradigmaties bepaald dat die metodes as sodanig onversoenbaar is nie $e^{9}$. Die weë gaan weer uiteen wanneer resultate waartoe die verskillende metodes die navorsers gebring het, in die lig van hulle paradigmas geïnterpreteer word.

Die metode wat gebruik word, staan dus nie heeltemal los van 'n bepaalde paradigma nie (vgl. Kuln, 1970:48). Die siening van die Bybel (paradigma) kan ook 'n invloed hê op die metode wat gebruik word, of juis nie gebruik (wil) word nie. Dit is belangrik dat navorsers wat verskillende metodes in hul werk implementeer, sal kennis dra van die vooronderstellings wat onderliggend is aan al die metodes wat op die mark is. Dit impliseer dat alle metodes krities beskou sal word

\section{Die persepsie aangaande die Hervormingsparadigma}

\section{1 'n Geslote sisteem?}

Wanneer daar gelet word op enkele uitsprake van Gerefonneerde OuTestamentici, veral met betrekking tot Skrifbeskouing (vgl. Lion-Cachet, 1987:6, Helberg, 1983:7, 1988:1; H.F. van Rooy, 1994a:551), kan aan die hand van Spangenberg se omskrywing van die verskillende paradigmas die afleiding gemaak word dat hierdie teoloë werk vanuit die paradigma van die Hervonning, omdat hulle na die Bybel verwys as die "Woord van God". Die persepsie wat allerweë met betrekking tot hierdie paradigma bestaan, is dat dit 'n geslote paradigma is. In G. Snyman (1992b:361) se woorde is dit "'n geslote lewensvisie wat waagmoedige kreatiwiteit ondermyn, gebrek aan selfkritiek, oorskatting van die eie teologiese sisteem as waarheid en 'n totalitêre sisteem waarmee konsensus afgedwing word ... [hierdie sisteem] dwing teologiese besigwees [in die GKSA] in 'n ghetto in". (Vgl. ook Spangenberg, 1994:174-175; G. Snyman, 1992a:249, J. Botha, 1991:213; J.J. Snyman, 1991:11, 12.)

9 Vergelyk in hierdic verband dic debat tussen Loader (1994) en Le Roux (1995) waanut dit duidelık is dat dic paradigma dic aksente van die navorser bepaal. Wanneer twee metodes vanuit cen paradigma gebruik word, sal die paradigma dic navorser se fokus bepaal. So is Loader se fokus inderdaad mecr literêr van aard, alhocwel hy ook histories-kritics wil uerk. 
'n Paradigma vir Gereformeerde teologiese wetenskapsbeoefening - 'n voorstel

Die vraag waarom hierdie persepsie bestaan, kan onder andere beantwoord word deur ook hand in eie boesem te steek. Dit blyk dat daar in die verlede deur Gereformeerde teoloë gemeen is dat Skrifbeskouing en metode van Skrifverklaring noodwendig hand aan hand gaan (dieselfde siening as wat Spangenberg [1994:161] huldig). Tradisioneel word daar binne Gereformeerde kringe aan die "histories-letterlike verklaringsmetode" vasgehou. Volgens Deist (1994b: 173) word die teks binne hierdie verklaringsraamwerk gesien as " $n$ reservoir van betekenis" wat, deur eksegetiese metodes 10 "objektief getap kon word". $\mathrm{Na}$ hierdie siening kan ook verwys word as die enger siening van hermeneutiek. Hierdie siening aangaande hermeneutiek word vervolgens gekoppel aan die Skrifbeskouing binne hierdie navorsingsgemeenskap.

\subsection{Die invloed van Skrifbeskouing op Skrifverklaring}

Onder hierdie hoof wil aangetoon word hoe die siening van 'n te noue band tussen Skrifbeskouing en die metode van Skrifverklaring in die verlede aanleiding kon gegee het tot die bestaande persepsie van geslotenheid met betrekking tot die Hervormingsparadigna. Dit is belangrik om die volgende aanhalings van LionCachet en Helberg se navorsing binne hierdie konteks te sien. Daar word gewys op 'n mate van ontwikkeling in die metode(s) van Skrifverklaring wat aangewend word. Verder word aangetoon hoe die persepsie van die Hervormingsparadigma as 'n geslote paradigma tot 'n mate toegeskryf kan word aan die metode van Skrifverklaring wat vir 'n lang tyd gebruik is. Die "grammaties-historiese" metode is gesien as in tandem met die Hervormingsparadigma se siening van die Bybel as Woord van God. Dit is reeds aangetoon op grond van Kuhn se beskrywing van 'n paradigma dat Skrifverklaring (metode) nie noodwendig hoef saam te hang met Skrifbeskouing (paradigma) nie.

Lion-Cachet (1987:6) meen met betrekking tot Skrifverklaring: "Die Bybelboeke is so geskrywe dat die eenvoudigste mens dit kan verstaan ..." en ook (1987:9): "Wie werklik na die stem van die Here wil luister, kan dit alleen doen as die Gees jou in alle waarheid lei". Hierdie aanhalings is in ooreenstemming met Spangenberg (1994:148) se opsomming van die Hervormingsparadigma. Die rede waarom hierdie uitsprake die indruk van geslotenheid skep, kan moontlik wees omdat die Heilige Gees in hierdie benadering as 'n "soort skuiling" gebruik word waarteen niemand mag stry nie (G. Snyman, 1992:261). Die verklaringsmetode wat deur Lion-Cachet (1989:1; vgl. 1987:50) voorgestaan word, is die "'letterlike' verstaan" of die grammaties-historiese metode. Binne hierdie benadering kry die agtergrondsraamwerk valı die spreker en hoorder (Lion-

10 Helberg (1983:109) verstaan onder hermencutick juis hicrdic "recls vir eksegese". Sclfs vanuit "behoudende" kringe word hermeneutick egter vandag beskou as "the overall term while exegesis [is an aspect] of that larger task" (Osbomc, 1991:5) 
Cachet, 1987:26 e.v.; vgl. 1989:3), asook die strukturele ontleding van die teks (Lion-Cachet, 1987:71) wel aandag. Laasgenoemde ondersoeke staan egter in diens van die "letterlike verstaan" en dra nie betekenis los daarvan nie (vgl. LionCachet, 1991a:99). Dit blyk dat Lion-Cachet in latere publikasies (vgl. 199la, 1991b) afwysend staan teenoor veral die histories-kritiese metodes van ondersoek.

In een vall hierdie studies (Lion-Cachet, 1991a:98) word 'n dogmatiese (eerder as 'n historiese) vertrekpunt gekies vir die bespreking van die Christusgetuienis in die Ou Testament. Hierdie vertrekpunt, tesame met die stelling dat met die "finale teks" van die Ou Testament gewerk word (1991a:99), beïnvloed die gevolgtrekking waartoe gekom word (vgl. 1991a:111), naamlik dat "[o]ns alleen op grond van die getuienis van die Nuwe Testament aanvaar dat God Christus reeds afgebeeld het in die geskiedenis, die seremonies en sekere persone van die ou bedeling". Die beswaar teen hierdie benadering is dat die teks van die Ou Testament as sodanig nie altyd emstig geneem word nie. Die volle konsekwensie van hierdie vertrekpunt word duidelik in die laaste konklusie (1991a:111): "Die algemene en besondere belydenisskrifte van eenheid in die Gereformeerde Kerke kan steeds op grond van die Ou en Nuwe Testament as 'n betroubare voorveronderstelling en riglyn vir die verstaan van die Christus (sic) in die Ou Testament geneem word" (my kursivering - HJMvD). Die vraag ontstaan egter of ' $n$ historiese vertrekpunt dieselfde resultaat sou lewer? Moet daar nie eerder histories (of literêr) te werk gegaan word om die leer (dogma) te toets nie, al sou dit beteken dat die leer (dogma) moontlik aangepas moet word. Dit gaan hier dus on metode en die vraag of 'n navorser bloot 'n metode mag kies wat sy reeds ingenome (konfessioneel-bepaalde) standpunt sal staaf?

In 'n jonger publikasie (Lion-Cachet, 1994) waarin 'n ondersoek geloods word na die begronding van geregtigheid vanuit die wettebundels, word die vertrekpunt egter gewysig: "In die ondersoek word eerstens met die historiese tydsgerigtheid en literêre konteks rekening gehou ..." (1994:247) (my kursivering - HJMvD). Hierdie verskuiwing in vertrekpunt moet verwelkon word, maar die vraag mag seker gevra word of hierdie vertrekpunt gekies sou gewees het indien dit sekere konfessionele implikasies sou hê?

Rondom Skrifverklaring merk Helberg (1983:1) op dat alhoewel die vooruitgang in ander wetenskappe, wat die verklaring van geskrifte in die algemeen bestudeer, beskou kan word as van waarde vir Skrifverklaring, "[dit] ook grense [het]". Verder meen Helberg (1983:9) in ooreenstemming met die Hervorningsparadigina: "Vir ware Skrifverklaring is die geloof en die leiding van die Heilige Gees ... noodsaaklik", so nie bly die Bybel geslote en word dit bloot as 'n menslike boek gesien (vgl. Deist \& Burden, 1983:100). 
Hierdie "tradisionele" vertrekpunt van Helberg, word egter in sy latere werk nie gesien as bepalend vir die metode van ondersoek nie. In sy eksegese van Psalm 36 maak Helberg (1990:466) onderskeid tussen drie literêre soorte in dié psalm (vgl. Burger, 1987:22-29). Verder word hierdie psalm ook nie bloot getipeer $(1990: 471,477)$ asof dit uitsluitlik met die kultus te make het nie (vgl. Burger, 1987:22), terwyl daar ook melding gemaak word van mitologiese voorstellings (Helberg, 1990:466) waarby daar in die psalms aangesluit word, sonder om beskouings wat daarin vervat is oor te neem (vgl. Burger, 1987:33). In hierdie geval maak Helberg dus gebruik van literêre en historiese metodes en resultate. Helberg (1990:465) staan tog (op beredeneerde gronde) afwysend teenoor 'n lang redaksiegeskiedenis van Psalm 36, maar praat eerder van 'n "onverwagte wending" (Helberg, 1990:470) in die psalm waar die histories-kritiese metode die samevoeging van twee bronne suggereer. Die historiese metode word dus nie klakkeloos nagevolg nie, maar ook gekritiseer.

Helberg (1991:116) gaan in 'n ander bydrae, wat mooi perspektiewe bied op die dienende plek van die belydenis ten opsigte van die Skrif, uit van 'n eenheid in die boek Jesaja. Tog baat sy argument by die erkenning van die verskillende historiese agtergronde waarteen die verskillende dele van die boek ontstaan het, deurdat die teks van byvoorbeeld Jesaja 40 met 'n ander historiese situasie in verband gebring word as die teks van Jesaja 1-39 (vgl. Helberg, 1991:124, 133). Weereens dus die gebruik van sekere resultate vanuit die histories-kritiese skool.

Hierdie gebruik is egter nie konsekwent nie en so is dit in 'n latere publikasie (Helberg, 1992:245) nie duidelik of Helberg onder Groot Profete die geskrifte of die persone Jesaja, Jeremia en Esegiël in die oog het nie, alhoewel dit lyk asof na die persone self verwys word. Die verskille tussen Jesaja en Deuterojesaja word egter wel later in laasgenoemde studie (Helberg, 1992:248) in die argumentasie verdiskonteer. In hierdie artikel word daar veral uitgegaan van openbaringshistoriese gegewens (vgl. Helberg, 1995). Die gevaar van 'n a-historiese lees van die teks (vgl. H.F. van Rooy, 1995:63) is daarom te bespeur in hierdie artikel

In die verklaring van Psalm 42 en 43 neem Helberg (1993:110) kennis van 'n bepaalde historiese agtergrond waarteen die psalm beskou kan word (vgl. Burger, 1987:18). Tog word die uitspraak van Helberg (1993:112) dat "die lied nie 'n naballingskapse ontstaan [hoef] te hê nie", die vertrekpunt wat die uiteindelike gevolgtrekking beïnvloed (1993:121). Helberg (1994:77 e.v.) werk in sy verklaring van die belydenis van Danie|l11 se vriende ook met die resultate van die

11 H.F. van Rooy (1995:63) beoordecl Helberg sc kommentaar op dic bock Danicl gunstig, terwyl J A. van Rooy (1995:539) kritick daarop uitspreck ondat Helberg sonder motivermg met betrckking tot Danicl 7 kies vir 'n verklaring wat oorenkom met "die van Skrifkritiese tcoloe". 
historiese kritiek, veral ten opsigte van die datering van die perikoop (Daniēl 3) (teenoor Baldwin [1978:46] en Aalders [1962:29]).

Daar is reeds verwys na H.F. van Rooy se gebruik van verskillende metodes van Bybelverklaring vanuit die Hervormingsparadigma. Daar word dus nie in hierdie verband weer na H.F. van Rooy verwys nie. Die navorsing van H.F. van Rooy is 'n goeie voorbeeld van die ontwikkeling in die Gereformeerde teologie na die gebruik van meerdere metodes en die resultate wat daardie metodes opgelewer het. Dit is verder duidelik uit die bostaande bespreking van die navorsing van Lion-Cachet en Helberg dat hulle ook begin gebruik maak van ander metodes in hulle verklaring van die Bybel as Woord van God (vgl. Armending, 1983:19). In hierdie verband is nie al die navorsing van die drie Ou-Testamentici hier bespreek nie. Daar wil slegs aangetoon word dat, veral met betrekking tot die ouer werke, die persepsie van geslotenheid wat daar bestaan aangaande die Hervormingsparadigma wel geregverdig was, maar dat daar 'n merkbare ontwikkeling in die beskouing en gebruik van ander metodes is.

\subsection{Binding aan die belydenis}

Die rede waarom daar tradisioneel so 'n noue band gehandhaaf is tussen die Skrifbeskouing en metode van Skrifverklaring kan moontlik lê in sommige resultate wat verkry is met behulp van ander metodes van Skrifverklaring. Hierdie resultate het soms gebots met die sestiende-eeuse belydenis. Die histories-kritiese skool het byvoorbeeld op goeie gronde aangevoer dat Moses nie die skrywer van die Pentateug was nie, terwyl navorsers wat met die resultate van die histories-kritiese skool sowel as die literêre skool werk, van mening is dat die Pentateug die produk van die na-ballingskapgemeenskap is (vgl. Blenkinsopp, 1992). In die NGB art. 4 word egter na die Pentateug verwys as "die vyf boeke van Moses", die oorwoë siening gedurende die sestiende eeu (vgl. verder die "profete" Jona en Daniel). Deur die tradisionele outeurskap van Moses met betrekking tot die Pentateug te ontken, word die gesag van die Bybel nie ontken nie; nog minder word ontken dat die Bybel die Woord van God is ${ }^{12}$

Wanneer die Ou-Testamentiese navorser die resultate van ander metodes begin gebruik, is die gevaar van dualisme egter groot ${ }^{13}$. 'n Navorser kan nie sy intellek kompartementaliseer nie (vgl. Silva, 1994:259). Die commument aan die Bybel as God se Woord kan nie ter wille van 'n "neutrale" bespreking ingeruil word nie.

12 Kyk in hierdic verband Longman (1987) se sicning van die bydrae wat die literêre kritiek kan mak inct betrekking tot Skrifverklaring.

13 F.E. Deist word vanuit sommige kringe juis van "skisofrenicse tcologiese denke" beskuldig (vgl. Doubell \& Strauss, 1995 479). 
Tog is daar ook binne die teologiese wetenskap ${ }^{14}$ 'n uitsondering op hierdie stelling. In die woorde van Wolterstorff (1984:94): "Sometimes [the Christian scholar] should allow scientific development to induce revisions in what he views as his authentic Christian commitment" (kursivering - Wolterstorff). In dieselfde trant, alhoewel versigtiger geformuleer, meld Silva (1994:264): “The result [of biblical study - HJMvD] should be increased sensitivity to those features of the text that disturb our interpretive framework and thus a greater readiness to modify that framework". Tereg merk Silva egter voorts op dat ons psigologiese ingesteldheid op hierdie punt ongelukkig oorneem en dikwels so 'n aanpassing verhoed. Die konfessionele grenslyne kan (en moet!) dus verskuif word indien daar deur resente navorsing iets in die teks gevind word wat die konfessie weerspreek. ${ }^{15}$ Du Plooy (1991:76) meld in hierdie verband: "[d]ie binding aan die belydenisskrifte was nooit en mag nooit bedoel word as 'n lastige faktor wat die wetenskap van die teologie aan bande lê nie"16

Gesien die ideaal van semper reformanda van die Reformasie is dit jammer dat die Hervormingsparadigna tot 'n groot mate steeds die persepsie van 'n geslote paradigma skep. Die refonnatoriese ideaal kan herleef indien navorsers van meer metodes gebruik maak, sodat die Bybel as God se Woord 'n woord vir die huidige tyd met sy huidige (ook teologiese) vrae kan spreek.

\section{5. 'n Herontdekking van wat die Hervormingsparadigma behels}

Die paradigma waarbinne die teologiese wetenskap aan die Fakulteit Teologie van die PU vir CHO beoefen word, word nie uit daardie geledere duidelik omlyn nie. Vergeer (1993:575) gee toe dat 'n presiese omskrywing van die "Gereformeerde paradigma", soos hy daama verwys, nie bestaan nie, alhoewel hierdie nieduidelik omlynde paradigma gestel word teenoor die paradigma van die "“nuwere' teologiese hermeneutiek" (Vergeer, 1993:566-568), waaruit G. Snyman (1992a, 1992b) volgens Vergeer werk. In hierdie artikel is daarop

14 Daar word hier uitgegaan van die standpunt dat teologic aan 'n universitcit bestudecr word, omdat dit 'n bydrae te lewer het tot dic "algemene wetenskaplike insig in die hele werklikheid wat deur die universiteit bestudeer word" (Deist, 1994a:60).

15 Vergelyk Van Wyk (1995:253) wat meen dat dit feitlik ondenkbaar is dat al die ckscgetiese werk en Skrifondersock wat sedert dic Reformasic gedoen is, nic tot nuwe belydenisvorming sal stimulecr nie

16 Rhem (1985/6) lewer 'n sterk pleidooi vir dic aanpassing van die belydenisskrifte om tred te hou met dic kennisontploffing in die wetenskappe Dit is die enigste manicr waarop "a church confident of the truth as it has come to expression in Jesus Christ will find the present day an exciting day in which to identify the questions and find the appropriatc mode in which to witness to the sclf-disclosure of God in the face of Jesus Christ" (Rhem, 1985/6:253) (my kursivering - HJMvD). 
gewys dat die paradigma waaruit teologie aan die PU vir $\mathrm{CHO}$ beoefen word, geklassifiseer kan word as die paradigma van die Hervorning, vanweë die Skrifbeskouing van hierdie navorsingsgemeenskap.

Die "'nuwere' teologiese hermeneutiek" waaroor Vergeer (1993) dit het, het egter te doen met metode van Skrifverklaring en hoef dus nie 'n gevaar vir die bestaande paradigma in te hou nie. Daar is hierbo aangetoon hoe daar by OuTestamentici aan die $\mathrm{PU}$ vir $\mathrm{CHO}$ 'n breëre siening van die hermeneutıek, waarna Vergeer (1993:566) verwys as die "nuwere hermeneutiek", besig is om te ontwikkel. Volgens hierdie siening word die verstaan van 'n teks ook gekoppel aan ander "reservoirs" (Deist se vergelyking), soos byvoorbeeld bepaalde histories-kritiese, literêre en sosiologiese oorwegings.

In die herontdekking van die Hervormingsparadigma sal daar binne hierdie navorsingsgemeenskap bewustelik wegbeweeg moet word van die uitsluitlike gebruik van die "listories-letterlike verklaringsinetode" (Spangenberg, 1994: 148), of 'n "naïef-realistiese17 benadering" soos G. Snyman (1992a:252, 259) na hierdie metode verwys. 'n Deeglike studie van die filosofiese vooronderstellings waarop hierdie "ou" verklaringsmetode rus, sowel as die vooronderstellings van ander hedendaagse metodes, sal ook tuishoort binne die Hervormingsparadigma. G. Snyman (1992:252 e.v.) het in verband met die vooronderstellings van die "tradisionele gereformeerde" metode die moontlikheid van Platonistiese invloede gesuggereer. ${ }^{18}$ Hierdie stelling roep steeds om beantwoording.

'n Herontdekking van die Hervormingsparadigma beteken verder dat, terwyl daar aan die Bybel as Woord van God vasgehou word, daar ook van meerdere metodes en resultate gebruik gemaak word in die verklaring van die Bybel. Dit behels inderdaad meer as blote openheid en kemnisname met betrekking tot dergelike metodes (vgl. Lion-Cachet, 1995:43), maar behels dat studente opgelei word in die gebruik van hierdie metodes en vertroud raak met die resultate daarvan. Die aard van wetenskapsbeoefening impliseer egter dat alle metodes (vanuit die eie paradigma) krities benader sal word met inagneming van die verskillende filosofiese vooronderstellings wat elkeen ten grondslag lê.

Die feit dat die Gereformeerde teoloog probleme mag hê met die filosofiese grondslae van die "ander" metodes, is geen rede om nie daardie metodes in te

17 Deist (1994c:37) koppel hierdic benadering tereg aan wat hy bestempel as Suid-Afrikaanse fundamentalısme

18

Dit is intercssant om daarop tc let dat Zuiddam (1995) op sy bcurt juis dic (historics) kritiesc omgang met dic Bybcl wil terugvocr na dic Middel- en Nco-Platonisme! 
span om te kom tot ' $n$ beter verstaan van die Bybel in die huidige konteks ${ }^{19}$ en daarmee saam tot ' $n$ beter verstaan van wat God aan die mens openbaar nie.

\section{Samevattend}

Hierdie artikel het gepoog om aan te toon wat die begrip paradigma binne die teologiese wetenskap behels. Die drie paradigmas wat in die teologie te bespeur is, verskil van mekaar met betrekking tot 'n grondstelling in verband met Skrifbeskouing. In die wetenskap is die paradigma waaruit gewerk word egter nie absoluut bepalend vir die metodes wat gebruik word nie. Vanweë die Skrifbeskouing aan die Fakulteit Teologie van die PU vir $\mathrm{CHO}$ is af te lei dat daardie navorsingsgemeenskap die paradigma van die Hervorming aanhang. Rondom hierdie paradigma het die persepsie egter ontstaan dat dit 'n geslote paradigma is. Hierdie persepsie kan onder andere begrond word in die uitsluitlike navorsingsmetode wat vir ' $n$ lang tyd gebruik is. Die jongste navorsing van Ou-Testamentici aan die PU vir $\mathrm{CHO}$ dui daarop dat daar ook van ander metodes gebruik gemaak word. Hierdie nuwe rigting is te verwelkom, ondat dit in die gees van en in ooreenstemming met die Reformasie is.

\section{Bibliografie}

AALDERS, G.C. 1962. Daniel (Commentaar op het Oude Testament) Kampen : Kok ARMENDING, C.E. 1983. The Old Testament and criticism. Grand Rapids : Eerdmans

BALDWIN, J C. 1978. Daniel. An introduction and commentary. (Tyndale Old Testament Commentaries.) Leicester : IVP

BEUKEN, W.AM 1994 The present state of Old Testament studies in Europe and foreseeable directions for the future. Old Testament Essays (Special Edition), 7(4):2532.

BNNGLE, H.J.J. 1976. A radical new order? (In Christian Higher Education - the contempory challenge. Proceedings of the first international conference of Reformed institutions for Christian sholarship, Potchefstroom 9-13 September 1975 Potchefstroom : Institute for the Advancement of Calvinism p 15-28.)

BLENKINSOPP, J 1992. The Pentateuch. An introduction to the first five books of the Bible New York: Doubleday.

BOTHA, J. 1991 Waarheidsteoriee en interpretasie Koers, 56(2): 185-215.

BOTHA, ME. 1989 Gespreksmoontlikhede tussen verskillende paradigmas Koers, 54(2): 190-207

BOTHA, ME. 1990. Metateoretiese perspektiewe op die sosiale wetenskappe Potchefstroom : PU vir CHO

BURGER, J.A 1987. Die Psalms. (In Burden, J.J. \& Prinsloo, W.S., reds Tweegesprek met God. Die literatuur van die Ou Testament dl 3 Kaapstad: Tafelberg $p$ 9-40.)

19 Silva (1994:251-259) gec op grond van dic sienıng van Calvyn met betrekking tot dic algemene openbaring 'n uitvocrige bespreking van hierdic stelling. 
H.J.M. van Deventer

CONRADIE, E M. 1994. Is the "new paradigm" in theology still new? (In Mouton, J. \& Lategan, B.C., eds. The relevance of theology for the 1990s. Pretoria : HSRC p 83105.)

DEIST, F.E. 1994a. Moet teologiese opleiding kerklik-konfessioneel wees? Hervormde Teologiese Studies, 50(1\&2):53-67.

DEIST, F.E. 1994b. Onlangse konsepte in teksuitleg en hulle konsekwensies vir die (gereformeerde) teologie. In die Skriflig, 28(2):165-178.

DEIST, F.E. 1994c. South African Old Testament studies and the future Old Testamemt Essays (Special Edition), 7(4):33-51.

DEIST, F.E \& BURDEN, J.J. 1983. 'n ABC van Bybeluitleg. Pretoria : Van Schaik.

DOUBELL, B \& STRAUS, S. 1995. Tussen kansel en kateder: aspekte van F.E. Deist se Skrifbeskouing. Nederduitse Gereformeerde Teologiese Tydskrif, 36(4):470-480.

DU PLOOY, A le R. 1991. Die aard en gesag van die binding aan die belydenisskrifte In die Skriflig, 25(1) 71-95

HASEL, G. 1991. Old Testament theology: Basic issues in the current debate ${ }^{4}$. Grand Rapids : Eerdmans.

HELBERG, J.L. 1983. Verklaring en prediking van die Ou Testament. Potchefstroom: PTP.

HELBERG, J L. 1988 Die Here regeer. Openbaringslyn deur die Ou Testament. Pretoria NG Kerkboekhandel.

HELBERG, J.L. 1990. Die PU vir CHO se naam, leuse en taak in die lig van Psalm 36 Koers, 55(4):463-480

HELBERG, J.L. 1991 Die verhouding van belydenis tot openbaring in die boek Jesaja In die Skriflig, 25(1):115-136.

HELBERG, J.L. 1992. Die basis en dryfkrag van die geregtigheidseis by die groot profete Koers, 57(2):241-259

HELBERG, J L. 1993 Die verbondsverhouding as basis vir klag en lof in Psalm 42 en 43 . In die Skriflig, 27(1):109-122

HELBERG, J.L. 1994. Die mag van God volgens die belydenis van Daniel se vriende. In die Skriflig, 28(1) 75-88

HELBERG, J L. 1995 Die korrektiewe aard van die Ou Testament en die betekenis daarvan vir teologiebeoefening In die Skriflig, 29(1\&2) 77-93.

JORDAAN, G.J C. 1991. Skrifbeskouing: Deurslaggewende faktor by Skrifverklaring (Wetenskaplike bydraes aan die PU vir CHO. Reeks H: Inougurele rede nr 125.) Potchefstroom : PU vir CHO

KUHN, T.S. 1970. The structure of scientific revolutions - second edition. Chicago University of Chicago Press

LATEGAN, B.C. 1984. Current issues in the hermeneutical debate. Neotestamentica, 18:117

LE ROUX, J H 1995 Die kontoere van 'n weerwoord Skrif en Kerk, 16(1) 82-101

LION-CACHET, F.N 1987. In die werkswinkel van die Ou-Testamentiese eksegese Potchefstroom : DSP

LION-CACHET, F.N 1989. So het dit begin - Gods boodskap in die raamwerk van die historiese boeke van die Ou Testament Potchefstroom : DSP

LION-CACHET, F.N 1991a. Die Christusgetuienis in die Ou Testament - 'n belydeniswerklikheid In die Skriflig, 25(1) 97-113

LION-CACHET, F.N. 1991b. Die rol van die priester in die "Troonopvolgingsgeskiedenis" Koers, 56(2):279-291.

LION-CACHET, FN. 1994 Die begronding van geregtigheid: 'n perspektief op die wettebundels van die Pentateug In die Skriflig, 28(2):247-259 
'n Paradigma vir Gereformeerde teologiese welenskapsbeoefening - 'n voorstel

LION-CACHET, F.N. 1995. Die spektrum en dinamiek van die Gereformeerde teologie. In die Skriflig, 29(1\&2):29-46.

LOADER, J A. 1994. Die weg van die Here in die woestyn oftewel God se grootpad in die wildernis: Oor A Story of Two Ways Skrif en Kerk, 15(2):391-413

LONGMAN, T. 1987 Literary approaches to biblical interpretation Grand Rapids : Academie.

MUSGRAVE, A.E. 1980. Kuhn's second thoughts. (In Gutting, G. ed. Paradigms and revolutions Appraisals and applications of Thomas Kuhn's philosophy of science. Notre Dame : University of Notre Dame Press p. 39-53.)

OSBORNE, G.R. 1991. The hermeneutical spiral. A comprehensive introduction to biblical interpretation. Downers Grove, Ill. : IVP.

OUWENEEL, W.J. 1993. Is 'n Christelike universiteit moontlik? Koers, 58(3) 321-339

RHEM, R.A. 1985/86. Theological method: The search for a new paradigm in a pluralistic age. Reformed Review, 39(3):242-254.

SILVA, M. 1994. (In Kaiser, W.C. \& Silva, M. Introduction to bibilical hermeneutics The search for meaning Grand Rapids : Zondervan )

SHAPERE, D. 1980. The structure of scientific revolutions. (In Gutting, G ed. Paradigms and revolutions. Appraisals and applications of Thomas Kuhn's philosophy of science. Notre Dame : University of Notre Dame Press. p 27-38.)

SNYMAN, G. 1992a Kenteoretiese besinning oor teologiebeoefening aan die Teologiese Skool Potchefstroom die afgelope twintig jaar. In die Skriflig, 26(2):247-266

SNYMAN, G. 1992b. Binnegevegte in die GKSA: verskuiwing van "plausibility structures"? In die Skriflig, 26(3):351-367

SNYMAN, J.J. 1991. Doppers se dilemma 'Stem van Potch' is stil Insig 10-12, Mei

SPANGENBERG, I.J.J. 1994. Paradigmaveranderinge in die Bybelwetenskappe. 'n Bydrae tot die gesprek tussen die Bybelwetenskappe en Sistematiese Teologie. Religie \& Teologie, 1(2): 144-184

VAN ROOY, H.F 1988 Eschatology and audience. The eschatology of Haggai. Old Testament Essays, 1(1):49-63.

VAN ROOY, H.F. 1993. The names Israel, Ephraim and Jacob in the book of Hosea. Old Testament Essays, 6:135-149

VAN ROOY, H.F. 1994a. Profetiese bediening: die Woord en sy hoorders. In die Skriflig, 28(4) $543-556$

VAN ROOY, H.F. 1994b. Prophet and society in the Persian period according to Chronicles. (In Eskenazi, T C \& Richards K.H., eds. Second temple studies 2 Temple and society in the Persian period. Sheffield : JSOT Press. p 163-179.)

VAN ROOY, H.F. 1995. Die bydrae en relevansie van die Ou-Testamentiese wetenskapsbeoefening in die Gereformeerde Kerke in Suid-Afrika (1869-1994). In die Skriflig. 29(1 \& 2):47-76

VAN ROOY, J.A. 1995. Resensie van Helberg, J.L. 1994. Die boek Daniel. In die Skriflig, 29(3): $538-539$

VAN WYK, J.H. 1995. Die relevansie van die Gereformeerde teologie vir vandag In die Skriflig, 29(1 \& 2):241-268.

VERGEER, W. 1993. Teologie en kenteorie. 'n Reaksie op die artikels van Gerrie Snyman. In die Skriflig, 27(4):563-582

WOLTERSTORFF, N. 1984 Reason within the bounds of religion². Grand Rapids Eerdmans

ZUIDDAM, B 1995. Old critics and modern theology. Nederdwits Gereformeerde Teologiese Tydskrif, 36(2):256-266. 